\title{
Down The LAdDer of Despair: The Holocaust Legacy of Itzhak Katzenelson
}

\author{
Moshe Shner \\ (Oranim Academic College of Education, Israel) \\ e-mail: mosheshner@gmail.com
}

Key words: Itzhak Katzenelson, Warsaw Ghetto, Theodicy, Despair, Holocaust Literature, Spiritual Resistance

\begin{abstract}
Holocaust historiography tries to offer a detailed and objective account of events, but it fails to grasp the inner world of its victims - those who perished and those who survived and carried its horrors in their souls. The hidden Holocaust is the dark abysses of the victims, their nightmares, and the despair they carry in their hearts to their last day, and in unclear ways pass it to the following generations.

The archives of the Ghetto Fighters' House Holocaust Museum at Kibbutz Lohamei HaGetaot in Israel holds the writings of the poet and educator Itzhak Katzenelson wrote during the Holocaust. His texts open a 'door' into the inner reality of the Holocaust, the shattered world of its victims. It is not scholarly historiographical writings, but rather a personal account of a sensitive person, a testimony, and interpretation of the real meaning of the Holocaust.

Before World War II, Katzenelson was a gifted teacher, part of his family Hebrew education system in Łódź, a prolific writer, poet, and dramatist. Many of Katzenelson's Hebrew poems became folk songs all over the Jewish Diaspora and in Palestine. His pre-war poetry was light, joyful, and childish in its character. His writings drew a bright picture of future Jewish life in the Land of Israel. His wartime writings were different, dominated by growing pain, rage, and finally despair.

Before the war, Katzenelson mainly wrote in Hebrew, the revived language of the Jewish people. Then, as part of the Jewish population, struggling for life under the iron yoke of the German occupation, he wrote in Yiddish, identifying himself with the fate of his brethren.

Katzenelson reached Warsaw in November 1939. In May 1940, he was 'adopted' by the 'Dror' (freedom) movement, becoming part of its underground educational and cultural work, offering words of consolation and hope to the ghetto people. However, as he witnessed the growing horrors of the Holocaust, including the loss of his own family, he could no longer give meaning to the terrible events and his life ended in total despair.

On April 1943, Katzenelson and his remaining son Zvi moved to the Arian side of Warsaw, imprisoned by the Gestapo and sent to the Vittel camp in France. Vittel was the last stage of his writings before his deportation in April 1944 to Drancy and then to Auschwitz to his death.

As we Follow Katzenelson's writings in Warsaw and Vittel, we descend a spiritual ladder from words of hope, through spiritual resistance to the bottom of the abysses of despair. Gradually, the joyful prophet of life became the prophet of darkness and a total loss of meaning. In his last writings, Katzenelson is bitter, poison to the soul, and yet with a sensitive pen and open heart, Katzenelson takes his readers down into the deepest chasms of history, showing them the reality of the Holocaust and its true meaning.
\end{abstract}




\section{A Hebrew educator in the Yiddish speaking Jewish Ghetto}

More than seventy years on, people try to understand the shattering event of the Holocaust, the destruction of Jewish life in Europe and the murder of about six million Jews, along with millions of other victims. Holocaust historiography tries to offer a detailed and objective account of the events, but it fails to grasp the inner world of its victims, those who perished and those who survived and continue to carry its horrors in their souls. The known Holocaust is the actions of the Germans, the war they waged against the Jewish people. The hidden Holocaust is the dark abysses of the victims, their nightmares, and the despair they carry in their hearts to their last day, and in unclear ways pass it on to future generations.

The archives of the Itzhak Katzenelson Ghetto Fighters' House at Kibbutz Lohamei HaGetaot (The Ghetto Fighters' Kibbutz) in Israel holds the Holocaust years' writings of the poet and educator Itzhak Katzenelson. ${ }^{1}$ His texts open the door into the inner reality of the Holocaust, the shattered world of its victims. His work is not scholarly historiography, but rather a personal account of the real meaning of the Holocaust.

In Katzenelson's texts - especially those he wrote during the last months of 1943 and in January 1944, in the concentration camp of Vittel, France - despair is blatant; they are probably unsuitable for the Israeli ethos of renewal and return to joyful life. Probably, this is why the Israeli culture of remembrance and Holocaust education programs tend to avoid them. Teachers do not introduce them to their students - they are too bitter. These texts contain the insights of a sensitive person who was in the midst of darkness, in the very depths of the abysses of history, but who could also detach himself from its harsh reality and write his reflections.

\footnotetext{
${ }^{1}$ Itzhak Katzenelson (1886-1944) — known as "the mourner of the Holocaust"-was born to his parents Yaakov Binyamin Katzenelson and his mother Hinda from the Davidson family in Karlitz Lithuania in 1886. His father was a "maskil" (modern Jewish scholar) and Hebrew writer who was ordained as a Rabbi but did not want to make Rabbinism his source of living. From him, Itzhak got his broad Hebrew education and a deep love to for his people. His mother came from a family of rabbis who had connections to the Hasidic movement in general and to the Chabad movement in particular.

In 1896 the family moved to Łódź in Poland and in 1906 Itzhak started to work as an educator in the family Hebrew school, part of the family network of Hebrew educational institutions which included a kindergarten, an elementary school and a gymnasium. Nonetheless, the language that was spoken in the Katzenelson family home was probably Yiddish. The Katzenelson family education projects were part of a flourishing of Jewish culture in Łódź, both in Hebrew and in Yiddish (Levinson 1945; Shner Zvi 1986: 73-76; Zur 2012).

In the years 1935-1939, Katzenelson led intensive cultural work in Łódź: teaching poetry, holiday parties, Shabbat evening celebrations ("Kabalat Shabbat") in the Borochove 'kibbutz hakhshara' ("preparation kibbutz') in Łódź. The Germans occupied Łódź on September 8, 1939. Katzenelson's Hebrew school was confiscated and the poet had to go into hiding, similar to other public figures whose heads the Nazis sought. As soon as he could, he escaped to Kraków, where he stayed for a couple of months, and then with help of friends he continued to Warsaw. He reached Warsaw around November $17^{\text {th }}-19^{\text {th }}, 1939$. His wife Hannah and his three sons, Zvi, Benzion and Benyamin, were arrested in November, shortly after the poet's escape, and deported to Kraków. From there they later escaped and joined him in Warsaw in January 1940. (Shner 2012; Zuckerman 1969, Zur 2012).

Zur's study is a major resource for information on Katzenelson's life and writings before World War II. Aside from Szeintuch's momentous study, Shner's 2012 study of Korczak and Katzenelson, and non-scholarly short introductions to Katzenelson's writings, we have no study of Katzenelson within the long Jewish tradition of martyrdom and theodicy.
} 
The Holocaust is a shattering event that brings chaos to the world, wiping out our moral horizons. Katzenelson's texts invite readers to an impossible reality with no meaning and no ethical directions - a return to nothingness. With the destruction of all meaning, cynicism and nihilism overrun the world.

Jewish culture, Biblical and rabbinic, created a large variety of responses to human suffering, especially through theodicy, which offers many ways to process the facts of evil in the world - its injustice, the pain, the existence of incomprehensible death - making them part of a known and meaningful reality. Otherwise, the monotheistic paradigm faces the danger of disintegration. At its core, Monotheism expresses a human aspiration for unity and meaning. The world has one overall explaining principle: the creator of the word, the almighty master of the world, who runs his world in justice. Why then do bad things happen to good people?

When the hypothesis of world justice is violated, Jewish, Christian, and Islamic traditions are required to defend themselves through theories of theodicy (God's justification), which hopefully will restore moral order in the world of men. From Biblical times, through all stages of Jewish history, Jewish thought tries to reconcile this hypothesis of an overall moral reality with the facts of life. ${ }^{2}$

History was not merciful to the Jewish people. In the Jewish collective mind, history gained a catastrophic image, and this is how it is presented in Jewish literary responses to catastrophe and in Jewish liturgy. Jewish historical culture has a whole tradition of Jewish martyrdom, 'Kiddush Hashem' (The Sanctification of God's Name in total devotion, including death). It is a form of radical theodicy, which tries to give meaning to the repeated persecutions of Jews in history. ${ }^{3}$

Itzhak Katzenelson was familiar with Jewish theodicy and the vast corpus of Jewish literary responses to catastrophe. From his arrival in Warsaw in the middle of November 1939, until his last days in the camp at Vittel in France at the beginning of 1944, he went through a spiritual journey in which he used various models taken from traditional Jewish theodicy in his efforts to give meaning to reality. It became harder and harder every day until it ended with the total destruction of his people. There and then, towards the end of 1943, Katzenelson could not find any more answers to the questions of Theodicy, and he ended his days in a total despair.

Katzenelson was versed in all layers of Jewish culture, but the Bible was his main cultural and spiritual resource. Trying to give meaning to reality, he uses Biblical language and engages in bitter dialogues with Biblical personalities. Sometimes he speaks like a Biblical prophet, sometimes he wrestles with the Biblical prophets, Jeremiah and Ezekiel.

Before the war, Katzenelson mainly wrote in Hebrew, the revived language of the Jewish people. Hebrew, the ancient language of the Bible, symbolized the future. The Zionist movement adopted Hebrew - after what is called in Zionist historiography 'the languages war' - as a platform for its efforts to revive Jewish life and Jewish culture in the Land of Israel. Israel was dreamed of, sung and discussed in Hebrew. Katzenelson had visited Israel-Palestine twice, and had seriously planned his immigration. Hebrew was his personal creative milieu. However, now, when he was part of the Jewish population

\footnotetext{
2 See: Birenbaum 1989; Gillman 1997; Roskies 1984; Roskies 1988; Shner 2013: 37-93.

${ }^{3}$ See: Roskies 1988; Shner 2011; 2013.
} 
struggling for life under the iron yoke of the German occupation, he wrote in Yiddish, identifying himself with the Jewish masses of the ghetto. The streets of 'Jewish Warsaw' spoke mainly Yiddish, not Hebrew, and Katzenelson saw himself as part of it.

As we follow Katzenelson's spiritual journey into the abysses of history, we can highlight four schematic stages in his Holocaust writings:

A. Warsaw, May 1940: a teacher and a spiritual older brother to the members of the 'Dror' (Freiheit, Freedom) movement, a source of condolence and spiritual resistance.

B. Warsaw, 1941: traditional theodicy of Kiddush Hashem (Martyrdom) as a spiritual answer to torture and sporadic acts of murder.

C. Warsaw, 1942: following the deportation of the ghetto population: God is helpless; only men can respond to the mass killing of Jews.

D. Vittel, France, November 1943-January 1944: total despair; the old prophecies of hope are irrelevant in the face of total destruction; nothing can be an answer to the reality of the Holocaust; the Heavens are empty; God is an ancient lie; the world lost its meaning.

Katzenelson, the joyful teacher, and poet, a messenger of hope about the revival of the Jewish people, descends the ladder of reality step by step and ends as an emissary of total despair. ${ }^{4}$

Until World War II, Katzenelson was overshadowed by other Hebrew writers of his generation. As a young member of Bialik's generation, he was not taken seriously. It was his role as a commentator on the reality of his people in the Holocaust years that gave him his unique place in Jewish history and drew attention to his prewar writings and pioneering Hebrew educational work in Łódź.

Katzenelson's dream was the Land of Israel, but the war caught up with him, and he was there with his people when their world was shattered. He shared their fate in the dying Warsaw Jewish ghetto.

The Zionist movement 'Dror' (Freedom) adopted Katzenelson and saved him from his loneliness among the hundreds of thousands of Jews imprisoned in the ghetto. They gave him a new milieu of creativity: a Bible teacher, a dramatist, a comrade and spiritual leader and the spokesperson of their inner feelings.

The ghetto walls were closing down on its inhabitants. In 1942, death approached the Warsaw Jewish ghetto. Katzenelson had lost his wife Hannah and two sons Benzion and Benjamin and had witnessed the horrors of the mass deportation to Treblinka. He cries, and curses, lamenting the loss of his family and his people.

Katzenelson's writings are more than a testimony-they are a commentary, a unique interpretation, an effort to give meaning to the events. In his writings, which partially survived the war, he invites us to the bottom of the abysses of history. If we could be there with him, we may get a better understanding what the Holocaust really is.

\footnotetext{
${ }^{4}$ My discussion of Katzenelson's ghetto writings is based mainly on Yehiel Szeintuch's momentous research, in which he showed the development of Katzenelson's work along eight stages as the reality of the ghetto deteriorated towards its total destruction. See Szeintuch 2000. Also in: Shner 2013: 176-201.
} 


\section{A messenger of hope and condolences}

Following the reorganization of the 'Dror' movement in May 1940, in the new reality of German occupation, Katzenelson had a creative milieu and a supporting audience. People used to associate the underground with the later, armed uprising in 1943, but the road that ended in armed fighting started with extensive spiritual and social resistance, including the activation of an agricultural farm in the city suburbs, the publishing of the underground press, the running of a school and drama groups and even a children's choir. $^{5}$

The underground educators' seminar, organized by Dror in May 1940 and then the establishment of the underground Dror gymnasium in August 1940 were, for Katzenelson, a forum for vital activity and a stage on which he could express his interpretation of the ghetto reality. The drama group that he established and the Bible reading evenings that he led were public stages where he could read his poems and in which he offered the people of the ghetto his empathy and interpretation of their reality, giving them hope and redemptive horizons.

His plays On the Rivers of Babylon (March 1941) and Job (June 1941) integrated Biblical chapters with the ghetto reality. Zivia Lubetkin, a leader of the Dror underground, testified in a retrospective about the importance of Katzenelson's plays in the life of the ghetto:

Yitzhak Katzenelson's biblical play Job appeared in the Dror Press. [...] Everyone who heard him read was inspired. It was evident that despite everything, the Nazis could not break our spirit; there were still creative forces amongst us. ${ }^{6}$

Lubetkin emphasized that the story of Job, apparently one of the darkest books of the Bible, was a source of inspiration for the inhabitants of the ghetto. Yitzhak Zuckerman (Antek), the leader of Dror remembered Job in a similar way: "This was very encouraging; indeed, it did not save anyone from death but raised up the head of the young people and the children" (Zuckerman 1990: 104. My trans. M.S.) Why did Katzenelson choose these Biblical stories? Why were dramatic plays, which deal with human agony and national disasters, a source of consolation?

The selection of these two Biblical topics, the story of Job and the Babylonian exile, was intentional. The plays themselves do not display high literary qualities, but they carry a vital message to their audience, and this is why they received such enthusiastic responses. Job deals with the suffering of the individual. On the Rivers of Babylon deals with the suffering of the collective. Both narratives depict dark events but have positive endings. In both plays, there is an effort to bring the present situation of the Jews into a narrative perspective, which promises its audience horizons of hope and redemption.

On the Rivers of Babylon stages for the ghetto people the reality of destruction and despair in antiquity. Psalm 137 represents best this hopelessness of the exiled:

\footnotetext{
5 Zuckerman 1993: 61-64, 104.

${ }^{6}$ Lubetkin 1981: 62.
} 
By the rivers of Babylon, we sat and wept, when we remembered Zion. [...] If I forget you, Jerusalem, may my right hand forget its skill. May my tongue cling to the roof of my mouth if I do not remember you if I do not consider Jerusalem my highest joy.

Remember, LORD, what the Edomites did on the day Jerusalem fell. "Tear it down," they cried, "tear it down to its foundations!"

Daughter Babylon, doomed to destruction, happy is the one who repays you according to what you have done to us. Happy is the one who seizes your infants and dashes them against the rocks.

The despair of the exiles is abysmal. In front of the mockery of their Akkadian capturers, the exiles have no answer, nor hope, just hopeless thoughts of bitter revenge. The despair of the ancient exiles touches - in Katzenelson's play - the despair of the ghetto Jews. The ancient psalm becomes a lyric tool with which the ghetto prisoners express the experience of their own destruction. This verse also gives them the words of the curse they wish will strike their oppressors.

The deeper the despair, the stronger the tidings concealed in the psalm for those who know the continuation of the ancient story, which the exiles did not know when they expressed their despair. Jews already know the good ending of this story: the exile came to an end in the year $538 \mathrm{BC}$, when those exiled who wanted to, returned to Zion. This ending is a glimpse of hope for the ghetto Jews. Maybe, like in the old story, their agony will end soon.

For the same reason, the story of Job carries with it a hope for a good ending. Indeed, the misfortune of Job was deep and horrible and the entire book is busy with Job's struggle with his unexplainable and apparently unjustified suffering, but the reader of the book already knows its positive outcome. God returns to the reality of Job. He hears God's words and his predicament is settled. Job gets back everything that he had lost and his world once again regained meaning. The ghetto inhabitants could hope for such a good end as well. Stories of victory and redemption are powerful means of theodicy. When people read their reality through a paradigmatic story, it becomes meaningful and bearable.

\section{The bravery of the proud spirit}

With the growing hardships in the ghetto and growing evidence of murderous acts in the regions under German occupation, the justification of reality and the consolation for the people became harder. The Nazi logic behind the reality of the ghetto became apparent as a logic of crawling destruction: isolation, hunger, cold, disease, brutal terror and, at the end, death.

Katzenelson finds words for the Jewish suffering in the ghetto. The "Songs of Hunger" (May 1941) and the "Songs of Cold" (February 1942) express the unbearable daily reality. A father looks with awful helplessness at his starving children and he cannot do anything to give them something to eat. In an outcry of despair, he says that they had better leave their home to die on the street. 
Manuscript of Song on Shlomo

Zelichovsky GFM archive \#19137

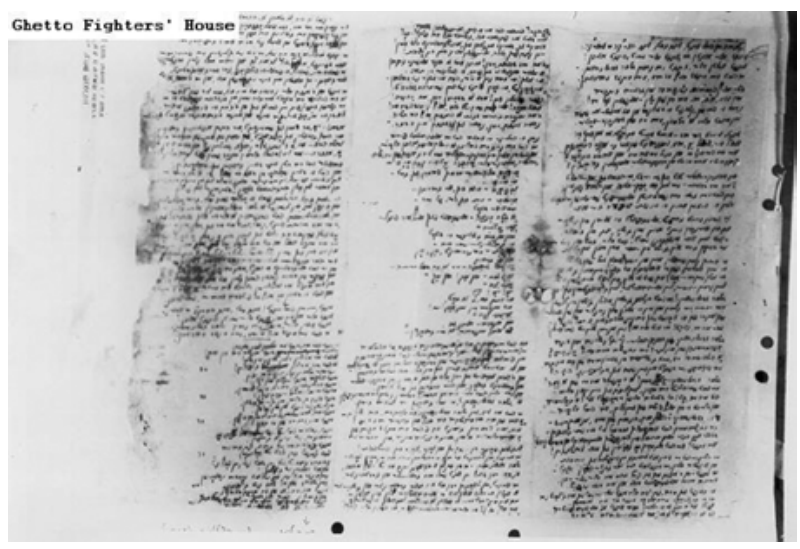

Katzenelson gives words to the cry of every parent in the ghetto who helplessly sees the agony of his or her children. Families could not overcome their reality and collapse. People left their homes. Children were left to their fate in the streets. Adolf Berman, the director of Centus, the Jewish children's aid organization, during the occupation years, described a reality of thousands of abandoned children among the 100,000 children in the ghetto (Berman 1973: 294-308). Jewish self-aid, as extensive as it was, could not give shelter to many of them. Emanuel Ringelblum, the head of the Jewish self-aid efforts and the noted ghetto reality historiographer, left us with a painful account of children's tragic reality in the ghetto: many were just living in the streets of the ghetto (Ringelblum 1992: 100, March 29 ${ }^{\text {th }}, 1940$ ). Jewish society started to disintegrate.

Reality is also terror and murder. The news about the fate of Jews in the occupied Soviet regions after June 1941, reached Warsaw. Katzenelson also tried to strengthen the spirit of his people in the ghetto in impossible circumstances. The poem 'Shlomo Zelichovsky' (June 1941) was written a year before the mass killing reached the ghetto itself. It is still stamped with traditional formulas of faithful strengthening - the heroic martyrdom, 'Kiddush Hashem'.

The poem describes a catastrophe: the Germans executed, on the evening of 'Shavuot'-(Pentecost) 1941 ten Jews from the Polish town of Zduńska-Wola in order to scare the population from performing acts of resistance and keep them in a constant state of terror and total obedience. Katzenelson describes the execution around the image of one of the executed Jews, the Hassid Shlomo Zelichovsky, who went singing - as it was told - to the gallows, calling the Jewish forced audience to keep their spirits high.

Sing, earth, and heaven, sing sing, God, sing, O, Lord.

Sing all you down there, sing all you here, sing all you above!

Sing, all the worlds, sing Shlomo Zelichovsky's name -

He lifted up Mankind; He lifted Man on high. (1969: 52) ${ }^{7}$

7 The poem was written in Yiddish following news that reached the Warsaw underground and was published in Yediot the journal of Dror on June $9^{\text {th }}$, 1942, about ten Jew in Zdunska-Wola who were hanged by the Germans in the town square. One Hassid, a devoted member of a Hassidic community, Shlomo Zelichovsky, who was among the ten executed, encouraged the spirit of the crowded Jews, forbade them to mourn and sang all the way to the gallows (1969: 371). 
Shlomo Zelichovsky was in his own mind, as well as in the imagination of the poet, a Jewish martyr in the long lineage of ancient Jewish martyrs who understood their approaching death as a 'holy death' and accepted it with joy.

'Kiddush Hashem', holy Jewish martyrdom, is a formula of theodicy. The decision to accept the coming death as holy is an interpreting decision. It gives holiness to a mere death and loads it with meaning. It turns political defeat into spiritual victory. For many generations 'Kiddush Hashem' was a form of response, which make it easier for Jews to accept their historical trial as well as an ideal example and ultimate moral compass for generations to come.

Rabbi Akiva, the most important Jewish martyr in Rabbinic tradition, died — as it is told in the Talmud - with a joyful declaration of faith (Babylonian Talmud, Berachot, 61: b). He died when he said the word "one" in the "Shema Israel' prayer, the ultimate Jewish declaration of faith. Rabbi Akiva's tradition inspired generations of Jews who went deliberately to their deaths when the only alternative was to blaspheme God and leave their faith (Shner 2011).

Shlomo Zelichovsky was sanctifying in his mind the name of God. He saw himself, as Rabbi Akiva in his time, gaining the highest privilege of becoming a martyr.

Rejoice! To die this way is a privilege

We are lucky! We stand before all Israel, in the sanctification of his name.

It is a great privilege to be hanged on the gallows!

Let's sing, Jews, let us break into melody! (1969: 54)

The act becomes also in the reality of Shlomo Zelichovsky-through the poetic interpretation of Katzenelson - an exemplary act for all Jews. "It is our fortune that we die like that" says Zelichovsky using the plural: we are the privileged. Now, as in the old days, it is the Jews' privilege to die with a declaration of faith on their lips and in their hearts.

There is one difference, however, from the rabbinic texts we can find in Katzenelson's text: while Shlomo Zelichovsky glorifies the name of God, Katzenelson glorifies the name of Man. It is the poet's interpretation. He uses the traditional idioms to give ultimate meaning not to God but to a person who shows such spiritual strength.

\section{The absurd bravery}

Reality did not bring in her wings consolation. Death penetrated to the streets and houses of the ghetto. News of the mass killings in the east of Poland and the Baltics by the special SS units that followed the advancing German army reached Warsaw. Consolation became impossible. In the summer of 1942, there began the mass deportation of the Jews of Warsaw to Treblinka.

On August 14, death touched Katzenelson personally when his wife Hannah and their two younger sons Benzion (14) and Benjamin (11) were among the thousands of deportees. Already on that day, the poet cried out his great loss in his Yiddish poem 'The Day of my Great Disaster'. His world collapsed and he could no longer find words of consolation. He becomes a poet of revenge who gives voice to the concealed words of his 
young comrades of the underground. He curses the Germans and their partners and he praises those who hold weapons and are intent on revenge.

After this bloody summer, Katzenelson's poetry becomes poetry of the absurd, rebelling against the traditional formulas of theodicy. Katzenelson and his underground comrades already know the reality of mass murder in all its grievousness. Death is not the fate of a few individuals, but the fate of the whole of the Jewish people. It is a genocide. Now all Jews were to become martyrs. One can no longer praise suffering and death as the sanctification of His name.

Suffering becomes unbearable. In the last great poem he wrote in the ghetto 'The Song of the Rabbi of Radzin' (November 1942-January 1943) he could no longer settle the absurdity of the Jewish reality. We encounter the bravery of a man struggling with no divine support in a reality that has lost its meaning. Trains of death travel throughout Poland telling the bitter truth: the world has lost all divine providence. It is a nihilistic world with no judgment and no judge.

Where do you go train cars? Say where you go?

To destruction, without law, without judge, to annihilation

"Without law and without a judge" - a voice of knocking, a loud voice:

Is it the wheels calling? Or Jews in the train cars? ${ }^{8}$

The world lacks basic justice, order and moral meaning. The Midrash, in an Epicurean-like formula, provides a better explanation: "There is no judgment and no judge -God left his world and settled in heavens" (Midrash Psalms, 10). The world is chaotic because it was left without any supreme guide, without Providence.

The reality of 1942 is the same-chaotic, with no Divine Providence. God is still an existing being, a present persona, but, as in the ancient Midrash, he is helpless and he cannot save his people. For Katzenelson, God is there - in the death train cars - but he can do nothing because of his ultimate weakness. This is an absurd theodicy, which Katzenelson draws from the reservoir of Jewish historical tradition: people suffer because God has lost his protective power.

The Rabbi learns about the fate of the Jews of Lublin. His efforts to move God to action fail. Man has to understand that he is on his own in this world.

Suddenly the Rabbi cries out through his cry and tears,

"Master of the World, I don't stand alone.

We two standing on guard here, you too

Look to Lublin from afar as it dies...

You too is hidden as I am here - you only look on...

Just like me, you cannot do anything to save your people...

I do not stand awake here alone between the walls -

You too... and the Rabbi wrings his hands. ${ }^{9}$

While God is helpless, "his hand is short", the Rabbi moves to action. In the last part of the Poem, when the death train travels throughout Poland, the Rabbi embarks on his grave mission, to bring the dead Jews in those train cars to a decent Jewish burial. He buys the dead and then buries them.

\footnotetext{
${ }^{8}$ Katzenelson 1969: 92 (Hebrew, my trans. M.S.)
}

${ }^{9}$ Ibid.: 96-97. 
In a picture of deep cosmic sadness, he approaches a car which seems empty, but then he hears a crying voice. He identifies God standing at the corner of the dark death train car and weeps. ${ }^{10}$ The Rabbi of Radzin listens to God's crying, but he can do nothing about it. He has no consolation, not even to the crying God.

The bravery of the Radzin Rabbi is the bravery of someone who is beyond despair or consolation. There is only one last task: to bring to burial those Jews who never got a grave. This is the outcry of Katzenelson: the Jewish people are dead and there is not even a grave for them. The Rabbi of Radzin listens to God, crying for his children, and he has no consolation, not from God and obviously not for men.

The cry of God in the corner of the train car brings forward another traditional connotation with which Katzenelson, versed in Jewish traditions of destruction, is well familiar. There is a Rabbinic Midrash $\left(5^{\text {th }}-7^{\text {th }}\right.$ century AD), which describes the Spirit of the Holy crying over its exiled children (The Midrash on Lamentations, 1). In the Talmud, the major rabbinic canon, we find the story of Rabbi Yossi, who heard the cry of God at the hind-part of the Holy of Holies, the inner part of the destroyed temple (Babylonian Talmud, Berachot, 3:1). The cry of the Shekhinah, the divine presence in the world, reappears in Modern Hebrew literature in a poem by Haim Nahman Bialik, 'Alone' (1901-1902). There, God is crying at the abandoned Beit Midrash. In Bialik's' youth, the Beit Midrash was the Holyof-the-Holies. Katzenelson was familiar with Bialik's poetry, as well as with the Midrash, and he took this motif one step further. In his poem, the Shekhinah is crying at the corner of the cattle train car. The train car is the Holy-of-the-Holies of this time. ${ }^{11}$

On January 1943, the Germans entered the ghetto and Katzenelson and his remaining son Zvi could not go out to the Tebens Shultz factory where they were registered, and had to remain with the underground comrades. ${ }^{12}$ They were among a 'Dror' fighting squad, on January 18, 1943, before the first battle on Zamenhof Street. Yitzhak Katzenelson's words on that day remain in the hearts of those who were privileged to hear them. Zivia Lubetkin, a leading member of the Jewish fighting organization (ZOB) has recalled in her memoirs the words of Katzenelson just before the January revolt began:

We should be happy that we are preparing ourselves, arms in hand, to meet the enemy and die if necessary. Our armed struggle will be an inspiration to future generations. [...] His words, spoken with holy fervor, lit a flame in our hearts. ${ }^{13}$

Now it was the time for men to take their fate in their hands. No God-only men could act. This was the meaning of the uprising: men would make their history. Antek Zuckerman, now the deputy commander of J.O.B., wrote in retrospectively about Katzenelson's place in the resistance movement: "[...] I announce that Yitzchak Katzenelson personally never had a pistol, and he never shot even one shot, and he didn't kill any German. But what he did was rebellion". ${ }^{14}$ One cannot understand the drive behind the decision to fight without the spirit of resistance that was part of the Jewish underground and had now turned into the spirit of uprising.

10 Ibid.: 125.

11 We can see that the cattle car was to become a common symbol of the Holocaust and a freight train car was placed in the yard of the Yad Vashem Holocaust Memorial Museum in Jerusalem.

12 Zuckerman 1993: 262, 281.

13 Lubetkin 1981: 151.

14 Zuckerman 1994: 45 [My translation, M.S.] 


\section{My people is no more}

Katzenelson was actually too old to take part in the fighting and, after the January 1943 battle, when the Jewish Fighting Organization prepared itself for the forthcoming uprising, Zuckerman decided to send the poet and his son Zvi to a hiding place.

Katzenelson did not listen to the warning of the underground and entered Hotel Polski, a supposedly secure place for people of foreign citizenship. The poet and his son had forged documents from Honduras and hoped that it would help them, but it was a Gestapo trap and they were sent to a concentration camp in Vittel, France. ${ }^{15}$

Katzenelson did not survive the Holocaust, but the several months in Vittel enabled him to respond to Jewish history. The diary he wrote in Hebrew, the 'Vittel Notebook', written from May 22, to September 161943 (Katzenelson 1969: 143-204), includes a detailed description of the Holocaust events, as well as a personal response to it. The diary shows an extensive knowledge of the fate of Jews in Europe and the 'Final Solution'. Katzenelson describes the process of mass killing in detail and states the number of "over six million" or even seven million Jewish victims (Katzenelson 1969: 189).

Katzenelson responds to reality as a commentator, as a Bible teacher and as a man of generations of Hebrew culture, one who searches for meaning in events. Jewish culture provides him with the proper vocabulary and lexicon to give words to what he sees. The loss of Hannah and his two sons, Benzion and Benjamin, is integrated in his writing with the loss of his people. Hannah is the image of all Jewish mothers. Benzion and Benjamin are the representation of all the murdered Jewish children. Personal grief merges with national grief.

Oh, my people! I called my people, I called my people and my people are no more... As my wife that was, as Benzion my son, as my Benjamin - they were, and now they are no more. And so are my people, there were my people, and now they are no more-killed. (Katzenelson 1969: 185, my trans. M.S.)

Katzenelson is attached to his people in his whole heart. The loss of his family and the loss of his people are one-an endless nightmare.

The diary includes a poem, which became a central element of the Ghetto Fighters' Museum liturgy of the Holocaust commemoration event:

I dreamed a dream

It was grievously sore,

My people had perished

It is no more, no more!

(ibid.: 187) $)^{16}$

Katzenelson states a terrible truth: a whole people was murdered.

15 Katzenelson's imprisonment in Vittel was known in the ghetto. See Ringelblum 1994: 233 and on p. 327 in Ringelblum's last letter from May 1, 1944 (a week before the Gestapo discovered Ringelblum's hiding place; he and his son were murdered, among many others).

16 In the GFM archives there are four versions of the poem in the poet's handwriting. The last version is from August $24^{\text {th }}, 1943$, and this is the one that was included in the diary. (See Katzenelson 1969: 382, note). 
This is not only a summary of hard historical facts but also an interpretive statement. Of course, not all the Jews in the world were murdered; nonetheless, murder and destruction of such magnitude meant nothing but the annihilation of a whole people. The poem puts forward an interpretive truth: the Jewish people was murdered.

Katzenelson expresses total despair. Insanity holds him. Where there is no consolation there is madness: "Shall I continue to record the annihilation of the whole nation, my nation? [...] This pen too is broken, like myself, like my soul, like everything with me". ${ }^{17}$ Everything died for Katzenelson: his pen, his heart, his soul.

Katzenelson knows that the murdered European Jews are only part of the Jewish people. I know - he says - that there are Jews in America and the Land of Israel and that they will have wonderful children, but all of them will not be a replacement for the murdered people. (Katzenelson 1969: 187; August 24 ${ }^{\text {th }}$, 1943) The living in the future are no substitute for the dead. He rejects now the good ending of Job. The loss is ultimate. Maybe, even the idea that life continues is unbearable. Therefore, he adds in the language of prayer his hope that despair will not crush those Jews from other places when they hear about the total destruction here.

His writings bear the connotation of the letter of support the prophet Jeremiah had sent to the Judean exiles in Babylon (Jeremiah, 29:4-6). Katzenelson refers ironically to the Biblical text to stress an opposite message. The old words of consolation are now the words of despair. Jeremiah wanted to say that there is a place for hope for renewal. Here, after the great deportation of the Warsaw Jews to Treblinka and the annihilation of millions of European Jews, there is no hope.

With the same ancient words, the prophetic message of consolation becomes a message of despair. Despair becomes the central theme in the diary. It is impossible to relate to, to touch with words, the millions of murdered Jews. The talk about "the millions" is an escape from the horror. One can refer to individuals, one person, another person, another individual. Then, one reaches despair. How one can say the ancient mourning prayer for one after the other, on into the millions.

\section{The dead bones will not return to life}

Katzenelson's great poem 'The Song of the Murdered Jewish People' — originally written in Yiddish, consists of fifteen cantos, each containing fifteen stanzas of four lines, written with a simple rhyme scheme-describes the chain of events he was witness to. Up to now it has not been properly explored and its pedagogical use has been nearly nothing. Its words are poison to the soul. In this poem, Katzenelson succeeded in expressing in depth the abyss where he was.

'The Song of the Murdered Jewish People' is a ballad, telling a sad story with a bitter ending. What is the opening scene of the story? The poet, carrying a harp, is presented as a troubadour who wants to express his story through the words of a song. He stands up in the ruined city street and calls his people to gather around him. Here is the first layer of the irony in his words: there is no living crowd to come as there are no more Jews. He

\footnotetext{
17 Katzenelson 1964: 187.
} 
is the last Jew. The poet calls his dead people to gather around him in a huge circle as in a huge dance.

12

Show yourself, my people. Emerge; reach out

From the miles-long, dense, deep ditches,

Covered with lime and burned, layer upon layer,

Rise up! Up! From the deepest, bottommost layer!

13

Come from Treblinka, from Sobibor, Auschwitz,

Come from Belzec, Ponari, from all other camps,

With wide-open eyes, frozen cries and soundless screams,

Come from marshes, deep sunken swamps, foul moss -

14

Come, you dried, ground, crushed Jewish bones.

Come, form a big circle around me, one great ring -

Grandfathers, grandmothers, fathers, mothers carrying babies.

Come, Jewish bones, out of powder and soap.

15

Emerge, reveal yourselves to me. Come, all of you, come.

I want to see you. I want to look at you. I want

Silently and mutely to behold my murdered people -

And I will sing... yes... Hand me the harp... I will play!

(October $3^{\text {rd }}-5^{\text {th }}, 1943$ )

(Katzenelson 1969: 309 , October $\left.5^{\text {th }}-10^{\text {th }}, 1943\right)^{18}$

The picture is horrible: all the dead Jews gather in a huge circle to listen to the last song sang, the lamentation, the elegy for themselves. After the image of the troubadour, comes the image of the Jewish minyan - the Jewish quorum for prayer and the chanting of the Kadish, the Jewish prayer for the dead, and words of lamentation and parting.

The poet becomes the prayer leader. There is no one to say the last prayer over the dead, so the poet summons the murdered Jews from the numerous places of death all over Europe, mass graves and heaps of human ashes, rivers, and swamps where the murderers threw the remains of the burned bodies. He asks them to say the Kadish for themselves.

In Wiesel's Night when Jews face their immanent death, they start to say Kadish for themselves. Here the image is even harder-he is summoning the murdered Jews to say the Kadish for himself or herself, as there is no one left to say for them the words of lamentation.

When the poet is calling all the dead to rise up from the valleys of death, death camps, swamps, and forests and gather around him in a huge circle, this connotes another image

18 This part of the poem, in which he tries - in a poetic imagination - to gather the dead was together with the previous text mentioned here from the Vittel Diary an essential part of the Holocaust liturgy at the public gathering in Kibbutz Lohamei HaGetaot. In the last decade these texts were removed from the Holocaust Remembrance program. 
with deeply exegetical meaning. Katzenelson's valley of the bones crushed to dust is the valley of the dried bones of Ezekiel: "The hand of the LORD was upon me, and the LORD carried me out in a spirit and set me down in the midst of the valley, and it was full of bones [...]" (Ezekiel, 37). Ezekiel's prophetic narrative is a classical Biblical metaphor for the hope of national revival. However, similar to Katzenelson's layers of references to Biblical literature elsewhere, here too the reference to Biblical imagery is overturned. Ezekiel's vision of the valley of the dried bones is not a prophetic vision of an actual resurrection of the dead. The dry bones that will be covered by skin and flesh and will return to life is a parable of hope about national resurrection, a source of hope for the exiles from Judea who will one day return to Zion. The exiles doubt the possibility of return and the prophetic vision may help regain their faith in the future or their people.

The exiled people, says the Biblical prophet, will eventually return to full national life. This return is dependent of course on repentance and spiritual renewal. This mending of the people's spirit is possible because man is now - as the prophet says - responsible only for his own conduct, for good and evil: "The one who sins is the one who will die. The child will not share the guilt of the parent, nor will the parent share the guilt of the child." (Ezekiel, 18:20) Katzenelson refers with irony directly to the consoling words of Ezekiel. In the face of total annihilation, even bones not left. "Not even a bone remains of my murdered people". (Katzenelson 1969: 310) The murdered Jewish people, whom he knew, will never return to life. "They are gone! They will never be back on this earth!"

The same Biblical words, words of hope, turned out to be words of despair. Ezekiel and Jeremiah's prophecies became a luxury or even a mockery of those who saw the reality of the murdered people. Katzenelson is the Jeremiah and Ezekiel of his time, but with a reversed message. Hope in the words of the ancient prophets merely adds contrast to the total despair in the words of the current prophet.

\section{Empty heavens}

With the collapse of the Biblical prophecies, the entire Jewish cosmos too collapsed, along with all its structures of meaning. Part 9 of the poem speaks about the deceiving "Heavens". Katzenelson does not wrestle with the question of God's existence. He is interested in a broader question: the very possibility of metaphysics. It is not a theological dilemma, but a humanistic question. 'Heaven' is a value-concept, which represents in Jewish-Christian and Islamic traditions the dwelling of God and the basic values of Good, Justice and mercy. The person who prays, raises his or her eyes and hands to the Heavens, beseeching support and redemption. The direction Up is the direction of the Good in our language and the direction down is the direction of failure and evil.

Spiritual directions have lost their meaning. Katzenelson describes a cosmic nothingness, a spiritual emptiness - the Heavens have betrayed men. "O, you deceitful, tricky, lowly heavens on high. How I regret that I once had faith in you, confided in you my joy, my loneliness, my smile and my tears, you are no better than this filthy earth, this big heap of trash!" (Katzenelson 1969: 331).

Katzenelson uses harsh words to describe the ethical nature of the Heavens: "vile whore" and "glittering like the eyes of mice". The Heavens promised good and demanded 
good, but they betrayed their believers. The Heavens saw the Jews taken to their deaths and remained silent. They are not a source of life, but empty and lifeless: "O you desolate, empty heavens, wide and desolate as the desert" (Katzenelson 1969: 333). The Heavens are meaningless. There is no God in the heavens as generations of naïve believers held. If the poem on the Radzin Rabbi portrays God as helpless, here in the last song, God does not exist. He is just a mere illusion or a deceit.

Not only has the present dramatically changed, but all of history is false, a great lie of thousands of years' indecent deceit: "You have always deceived us, lied also to my prophets, already to my prophets and my ancestors!" (Katzenelson 1969: 331). If all tradition is a big lie then there is no future, no present, and no past - everything is a false story.

Katzenelson, once a prophet of hope, the happy educator from Łódź, is now a prophet of despair. Step by step, he takes us down the ladder of despair to the bottom of the abysses of human existence, to the true reality of the Holocaust. The language of despair is the same language of Hebrew and Jewish traditions that he used in his educational work in Łódź before the war, the same connotations, the same metaphors, he used to construct his optimistic world. Now it is the language of a totally broken reality.

Katzenelson's final poem, 'The Song of the Murdered Jewish People', is a poetry of total despair. He does not offer his reader any way to escape the confrontation with the destruction of the world. It is a requiem to the Jewish people and an expression of the total loss of meaning in this world. The Heavens are revealed as desolate, a source of humanity's most prolonged illusion. The Jewish narrative has lost its validity. There is no past, no present, and no future. The Jewish people, he says ironically, have been just a fairytale, a passing dream.

Nonetheless, we have one spark of light. Katzenelson wrote for the generations of the future. He buried his last writings with the intention that they would reach post-war readers. He is doing this not as a historian, but as a commentator, a lamenter and a prophet, one who gives his audience an uncensored account of what we call "the Holocaust".

\section{BIBLIOGRAPHY}

\section{Itzhak Katzenelson Texts}

Katzenelson, Y. (1954), Yesh Li Shir [I have a Song, Hebrew], Tel Aviv: HaHistadrut HaKlalit and Hakkibutz HaMeuchad. (קצנלסון, יש לי שיר)

Katzenelson, Y. (1956), BeHalom Ubehakitz: Children Stories [In Wake and in Dream, Hebrew], Tel Aviv: HaHistadrut HaKlalit and Hakkibutz HaMeuchad. (קצנלסון, בחלום ובהקיץ)

Katzenelson, Y. (1964), Vittel Diary, Tel Aviv: Ghetto Fighters' House. (קצנלסון, פנקס ויטל)

Katzenelson, Y. (1969), Ktavim Acharonim [Last Writings, Hebrew], Tel Aviv: the Ghetto Fighters' Museum and Hakkibutz HaMeuchad. (קצנלסון, כתבים אחרונים)

Katzenelson, Y. (1975), Shirim [Songs, selection, Hebrew], Tel Aviv: the Ghetto Fighters' Museum and Hakkibutz HaMeuchad. (קצנלסון, שירים)

\section{Secondary literature}

Berman, A. (1973), The Fate of Children in the Warsaw Ghetto, in: Y. Gutman, L. Rothkirchen (eds.), The Holocaust: Background-History-Implications, Selected Articles, Jerusalem: Yad Vashem: 294-

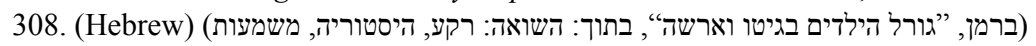

Birenbaum, D. (1989), God and Evil, Hoboken, N.J: Ktav Publishing House. 
Blumenthal, N. (1954), Yitzhak Katzenelson as Historian of the Holocaust Era [Hebrew], Yediot 5-6, April: 4-6. (Hebrew) (1954) (בלומנטל, "יצחק קצנלסון כהיסטוריון של תקופת השואה", בתוך: ידיעות) (1975). (1975),

Even Shoshan, S. (1975), Introduction, in: I. Katzenelson (1975). Shirim [Songs, selection, Hebrew], Tel Aviv: The Ghetto Fighters' Museum and Hakkibutz HaMeuchad: 289-319. (Hebrew) (מבן שושן, ("מבוא") בתוך: קצנלסון, שירים

Folman Raban, H. (2001), They Are Still with Me, Kibbutz Lohamei HaGetaot, Israel: the Ghetto Fighters' House. (Hebrew) (פולמן-רבן, לא נפרדתי מהם)

Gillman, N. (1997), The Death of Death: Resurrection and Immortality in Jewish Thought, Woodstock, Vermont: Jewish Lights Publishing.

Levinson, A. (1945), Lodz, my Hometown, in: Ben Yehuda Project, online at: http://benyehuda.org/ levinson/lodz.html (פרויקט בן יהודה).

Lubetkin, Z. (1981), In the Days of Destruction and Revolt, Hakibbutz Hameuchad.

Ringelblum, E. (1994), Notes from the Warsaw Ghetto, trans. J. Sloan, New York: McGraw-Hill Book Company. (Hebrew) (רינגלבלום, כתבים אחרונים: יחסי פולנים-יהודים, ינואר 1943 - אפריל 1944 (1964),

Ringelblum, E. (1992), Diary and Notes from the Warsaw Ghetto: September 1939-December 1942, רerusalem: Yad Vashem and the Ghetto Fighters' House. (Hebrew) (תמלינגבלום, יומן ורשימות מתקופת) (המלחמה: גטו וארשה, ספטמבר 1939 - דצמבר 1942 (1984), Against

Roskies, D.G. (1984), Against the Apocalypse, Cambridge, MA: Harvard University Press.

Roskies, D.G. (1988), The Literature of Destruction, Philadelphia: The Jewish Publication Society. Jerusalem: Magness Press (Hebrew) (שנר, בראשית הייתה השואה)

Shner, M. (2011), The Victim Refuses to continue to be a Victim, Yalkut Moreshet 89(6): 97-114.

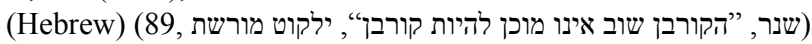

Shner, M. (2012), Janusz Korczak and Yitzhak Katzenelson: Two Educators in the Abysses of History, Tel Aviv: Tel Aviv University. (Hebrew) שנר, יאנוש קורצ'אק ויצחק קצנלסון: שני מחנכים בתהומות) (ההיסטוריה)

Shner, M. (2013), In the Beginning there Was the Holocaust: A Spiritual Journey into the Abysses of History, Jérusalem: Magnes Press.

Shner, Z. (1986), Ba'Mishmeret, Tel Aviv: Beit Lohamei HaGetaot and Hakibutz Ha'Meuhad. (Hebrew) (שנר צבי, במשמרת)

Szeintuch, Y. (2000), Yitzhak Katzenelson's Rescued Manuscripts: From the Warsaw Ghetto and the Vittel Concentration Camp, Jerusalem: Magness Press and the Ghetto Fighters' House. (Hebrew)

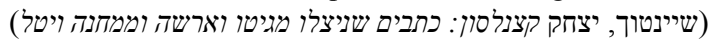

Zuckerman, Y. (1969), In Warsaw Ghetto and Vittel Camp, in: I. Katzenelson, Ktavim Acharonim [Last Writings, Hebrew]: 358-362. Tel Aviv: the Ghetto Fighters' Museum and Hakkibutz HaMeuchad. (Hebrew) (362-358, 1969, צוקרמן, מבוא, בתוך קצנלסון, כתבים אחרונים)

Zuckerman, Y. (1985), In the Ghetto and the Revolt [Hebrew], Tel Aviv: The Ghetto Fighters' House \& HaKibbutz Hameuchad. (Hebrew) (צוקרמן, בגטו ובמרד)

Zuckerman, Y. (1990), (Hebrew). Those Seven Years 1939-1946, Tel Aviv: Hakibbutz HaMeuchad \& BeitLohamei HaGetaot. (צוקרמן, שבע השנים החו)

Zuckerman, Y. (1993), A Surplus of Memory: Chronicle of the Warsaw Ghetto Uprising, Berkeley-Los Angeles, CA: University of California Press.

Zuckerman, Y. (1994), Zichronot VeDvarim shel Yitzhak Zuckerman [Hebrew], Edut 11. (Hebrew) (1994, 11 (צוקרמן, זכרונות ודברים, עדות)

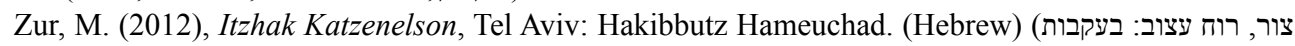
(יצחק קצנלסון 